RESEARCH ARTICLE

Published May 22, 2020

\title{
EVAluation OF UlTRAVIOLET-C Light For Rapid Decontamination of Airport SECURITY Bins In The ERA OF SARS-CoV-2
}

\section{AUTHORS}

Jennifer L. Cadnum ${ }^{1}$, Daniel F. Li ${ }^{1}$, Lucas D. Jones ${ }^{2}$, Sarah N. Redmond ${ }^{3}$, Basya Pearlmutter ${ }^{1}$, Brigid M. Wilson ${ }^{4}$, Curtis J. Donskey ${ }^{3,4}$

\section{AFFILIATED INSTITUTIONS}

${ }^{1}$ Research Service; Louis Stokes Cleveland VA Medical Center; Cleveland, Ohio

${ }^{2}$ Department of Molecular Biology and Microbiology; Case Western Reserve University School of Medicine; Cleveland Ohio

${ }^{3}$ Case Western Reserve University School of Medicine; Cleveland, Ohio

${ }^{4}$ Geriatric Research, Education, and Clinical Center; Louis Stokes Cleveland VA Medical Center;

Cleveland, Ohio

\section{CORRESPONDING AUTHOR}

DOI

Curtis J. Donskey 10.20411/pai.v5i1.373

Geriatric Research, Education, and Clinical Center

1110W, Louis Stokes Cleveland VA Medical Center

10701 East Boulevard, Cleveland, Ohio 44106

Phone: $216-791-3800$ ext. 4788

Fax: 216-229-8509

Curtis.Donskey@va.gov

\section{SUGGESTED CITATION}

Cadnum J, Li DF, Jones LD, Redmond SN, Pearlmutter B, Wilson B, Donskey CJ. Evaluation of Ultraviolet-C Light for Rapid Decontamination of Airport Security Bins in the Era of SARS-

CoV-2. Pathogens and Immunity. 2020;5(1):133-42. PubMed PMID. doi: 10.20411/pai.v5i1.373

\section{ABSTRACT}

Background: Contaminated surfaces are a potential source for spread of respiratory viruses including SARS-CoV-2. Ultraviolet-C (UV-C) light is effective against RNA and DNA viruses and could be useful for decontamination of high-touch fomites that are shared by multiple users. 
Methods: A modification of the American Society for Testing and Materials standard quantitative carrier disk test method (ASTM E-2197-11) was used to examine the effectiveness of UV-C light for rapid decontamination of plastic airport security bins inoculated at 3 sites with methicillin-resistant Staphylococcus aureus (MRSA) and bacteriophages MS2, PhiX174, and Phi6, an enveloped RNA virus used as a surrogate for coronaviruses. Reductions of $3 \log _{10}$ on inoculated plastic bins were considered effective for decontamination.

Results: UV-C light administered as 10-, 20-, or 30-second cycles in proximity to a plastic bin reduced contamination on each of the test sites, including vertical and horizontal surfaces. The 30-second cycle met criteria for decontamination of all 3 test sites for all the test organisms except bacteriophage MS2 which was reduced by greater than $2 \log _{10}$ PFU at each site.

Conclusions: UV-C light is an attractive technology for rapid decontamination of airport security bins. Further work is needed to evaluate the utility of UV-C light in real-world settings and to develop methods to provide automated movement of bins through a UV-C decontamination process.

Keywords: ultraviolet light; SARS-CoV-2; airport; decontamination; fomites

\section{INTRODUCTION}

The emergence of highly pathogenic respiratory viruses such as severe acute respiratory syndrome coronavirus 2 (SARS-CoV-2) highlights the need for effective measures to prevent viral transmission [1]. Respiratory viruses are shed in high concentrations in respiratory secretions [24]. Exposure to respiratory droplets and direct contact with contaminated individuals, including hand contact, are important routes of transmission []. The importance of contaminated surfaces and fomites in transmission is uncertain []ㅡ. However, respiratory viruses including SARS-CoV-2 can survive for hours to days on surfaces [ $\underline{5}-\underline{7}]$. Many studies have demonstrated recovery of respiratory virus nucleic acid on surfaces in healthcare and community settings such as households, day care centers, schools, and airports [모 $\underline{8}-\underline{13}]$. Based on this body of evidence, enhanced environmental cleaning and disinfection is recommended as a control measure for SARS-CoV-2 in healthcare and community settings [14].

Ultraviolet-C (UV-C) light is effective in killing RNA and DNA viruses [15-20] and is commonly used in healthcare facilities for post-discharge room decontamination as an adjunct to standard cleaning and disinfection [21-22]. UV-C technologies could also potentially be useful for decontamination of high-touch fomites that are shared by multiple users in healthcare or community settings [22]. The efficacy of UV-C light is substantially reduced with increased distance from the light source, on soft versus hard surfaces, and in areas out of the direct line of sight of the UV-C lamp [21-23]. Therefore, ideal fomites for UV-C decontamination would be hard, smooth surfaces that can be placed close to UV-C bulbs allowing short treatment cycles and that are not readily amenable to standard cleaning and disinfection processes that may be equally effective [22].

In the current study, we evaluated the potential for UV-C to be used for rapid decontamination of airport security bins. Security bins were chosen for study because they are repeatedly contacted by people and personal items in a setting with limited potential for alternative rapid decontamination strategies. In addition, recent studies have demonstrated frequent respiratory virus contamination of airport surfaces, including security bins [1ㅡㄴ $\underline{13}]$. Short UV-C cycles were studied 
because short exposure can be effective when items are close to the UV-C source [21-22, 24-25], and because decontamination of high-touch items between each use could potentially provide much greater benefit than intermittent decontamination after many uses.

\section{METHODS}

\section{Test organisms}

Table 1 shows the test organisms studied and their characteristics. The enveloped double-stranded RNA virus bacteriophage Phi 6 (Félix d'Hérelle Reference Center for bacterial viruses of the Université Laval HER 102) has been used as a surrogate for coronaviruses and influenza in previous studies [26]. Bacteriophage Phi6 was propagated in Pseudomonas syringae as previously described [26]. The bacteriophages MS2 and Phi X174 were propagated in Escherichia coli as previously described [27].

Table 1. Characteristics of the test organisms

\begin{tabular}{|l|l|l|}
\hline \multicolumn{1}{|c|}{ Organism } & \multicolumn{1}{|c|}{ Source } & \multicolumn{1}{c|}{ Characteristics } \\
\hline $\begin{array}{l}\text { Methicillin-resistant Staphylococ- } \\
\text { cus aureus (MRSA) }\end{array}$ & $\begin{array}{l}\text { Clinical isolate; pulsed- } \\
\text { field gel electrophoresis } \\
\text { type USA 400 }\end{array}$ & $\begin{array}{l}\text { Non-spore-forming Gram-positive } \\
\text { bacterium }\end{array}$ \\
\hline Bacteriophage Phi X174 & ATCC 13706-B1 & $\begin{array}{l}\text { Nonenveloped single-stranded DNA } \\
\text { virus (27 } \mu \mathrm{m} \text { particle size) }\end{array}$ \\
\hline Bacteriophage Phi6 & HER 102 & $\begin{array}{l}\text { Enveloped, double-stranded RNA } \\
\text { virus (85 } \mu \mathrm{m} \text { particle size) }\end{array}$ \\
\hline Bacteriophage MS2 & ATCC 15597-B1 & $\begin{array}{l}\text { Nonenveloped, single-stranded RNA } \\
\text { virus }(26 \mu \mathrm{m} \text { particle size })\end{array}$ \\
\hline
\end{tabular}

Abbreviations: ATCC, American Type Culture Collection; HER, Félix d'Hérelle Reference Center for bacterial viruses of the Université Laval.

\section{Efficacy of UV-C light for decontamination of security bins}

Testing was performed using a modification of the American Society for Testing and Materials standard quantitative carrier disk test method (ASTM E-2197-11) [28]. A large variety of different bin types are used in airports. The plastic bins selected for study were autoclave bins that are similar in size and shape to many bins used in airports. The bins were rectangular with length, width, and depth of $54,43.5$, and $13 \mathrm{~cm}$, respectively. For each pathogen, $10-\mu \mathrm{L}$ aliquots containing $10^{6}$ CFU or PFU of the test organisms were suspended in $8 \%$ simulated mucus [29] and were spread to cover 20-mm diameter circular areas on the bins and allowed to air dry. The inoculated areas included the bottom horizontal surface of the bin, the vertical side wall of the bin, and the horizontal top surface of the rim that is often gripped by hands (Figure 1). Two standard low-pressure mercury UV-C lamps each providing $426 \mu \mathrm{W} / \mathrm{cm}^{2}$ (Philips 30W bulbs, Cambridge, MA) with a target wavelength $254 \mathrm{~nm}$ were extended horizontally $7.6 \mathrm{~cm}$ apart at a height of 1 inch above the top edge of the bin. The UV-C lamps were operated for 10, 20, or 30 seconds delivering a fluence of $8,520,17,040$, and $25,560 \mu \mathrm{W} / \mathrm{cm}^{2}$ respectively. The short cycle time was chosen based on the presumption that rapid turn-around time would be essential for airport security bins. 


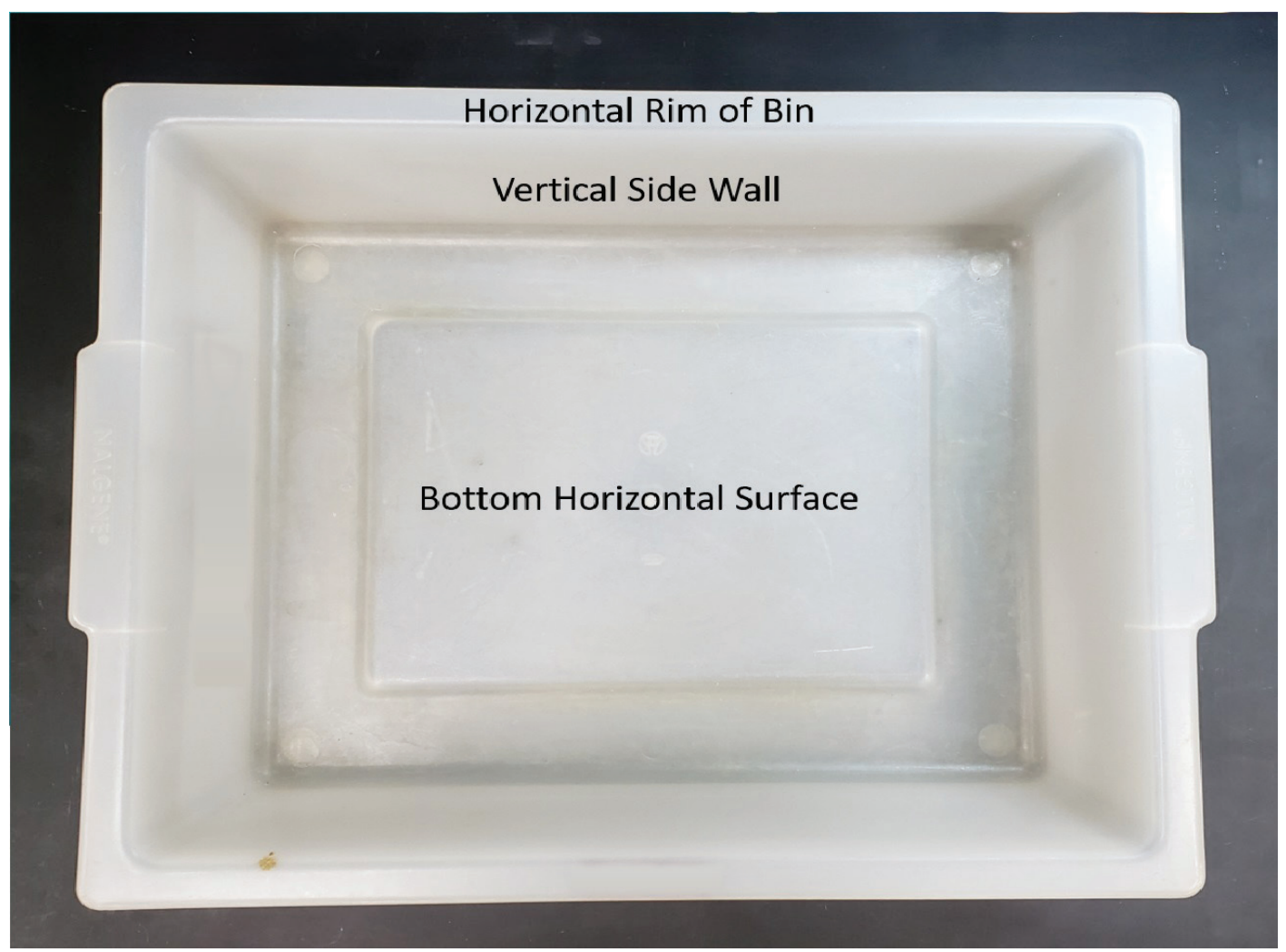

Figure 1. Pictures of the bin used for testing and areas where the test organisms were applied.

After the UV-C treatment, the inoculation sites were sampled using pre-moistened BD CultureSwabs (Becton Dickinson). The swabs were vortexed for 1 minute in $200 \mu \mathrm{L}$ phosphate-buffered saline with $0.02 \%$ Tween. Serial dilutions were plated on selective media to quantify viable organisms $[\underline{7}, \underline{24}, \underline{27}]$. All tests were performed in triplicate. Similar experiments were conducted with the test organisms inoculated onto 20 -mm steel disk carriers, spread to cover the surface area, and air dried. The swabs and disks were processed as previously described, and $\log _{10} \mathrm{CFU}$ or PFU reductions were calculated by comparing recovery from UV-C-exposed sites versus untreated controls.

For each UV-C experiment, a colorimetric indicator (UVC Dose Indicator, American Ultraviolet, Lebanon, IN) was placed adjacent to the inoculation site to provide a visual assessment of UV-C delivery to the bin.

\section{Data analysis}

There is no standard level of germicidal activity recommended for surfaces. Rutala et al. [30] has suggested that disinfectants that demonstrate a 3-log or greater reduction on carriers are likely to be clinically effective on surfaces. Although some investigators require 4-log or greater reduction in viruses as a requirement for virucidal activity [ $\underline{31}$ ], others consider a 3-log or greater reduction to be sufficient as an indication of effectiveness of a disinfectant [른 $\underline{34}$ ]. Therefore, for purposes of analysis, we considered a $\geq 3$-log reduction in recovery of organisms inoculated onto the bin surfaces to be effective for decontamination. 
Analysis of variance (ANOVA) was performed to compare the mean $\log _{10}$ reductions for the different organisms and for different UV-C exposure times. The ANOVA models adjusted for the different surfaces inoculated while assessing the parameters of interest. Least-squares means were considered for contrasts of interest. All analyses were performed using R version 3.5.1 statistical software (The R Foundation for Statistical Computing, Vienna, Austria) and functions from the emmeans package were implemented [하].$P$ values of less than 0.05 were considered significant.

\section{RESULTS}

Figure 2 shows the $\log _{10}$ reductions achieved on the surfaces of the plastic bins with 10-, 20-, and 30 -second treatments for the 3 bacteriophages and MRSA. Recovery of MRSA was reduced by $>3 \log _{10}$ CFU on all 3 locations on the bin surfaces with all 3 treatment times. Reduction differed significantly across organisms $(\mathrm{F}=47.1, \mathrm{df}=3, P<0.01)$, and reductions of MRSA were greater than reductions achieved for all the bacteriophages. Reduction also differed significantly with length of treatment $(\mathrm{F}=21.8, \mathrm{df}=2, P<0.01)$ and, averaging across organisms and sites, reductions with 30-second treatments were significantly greater than reductions with 10 - or 20- second treatments $\left(P<0.01\right.$ for contrasts). Reductions of $3 \log _{10} \mathrm{CFU} / \mathrm{PFU}$ were achieved with 30 -second treatments for all the organisms except bacteriophage MS2 which was reduced by $>2 \log _{10}$ at each site with a 30-second treatment. Similar results were obtained when the test organisms were inoculated onto 20-mm steel disks, spread to cover the surface area, and air dried.

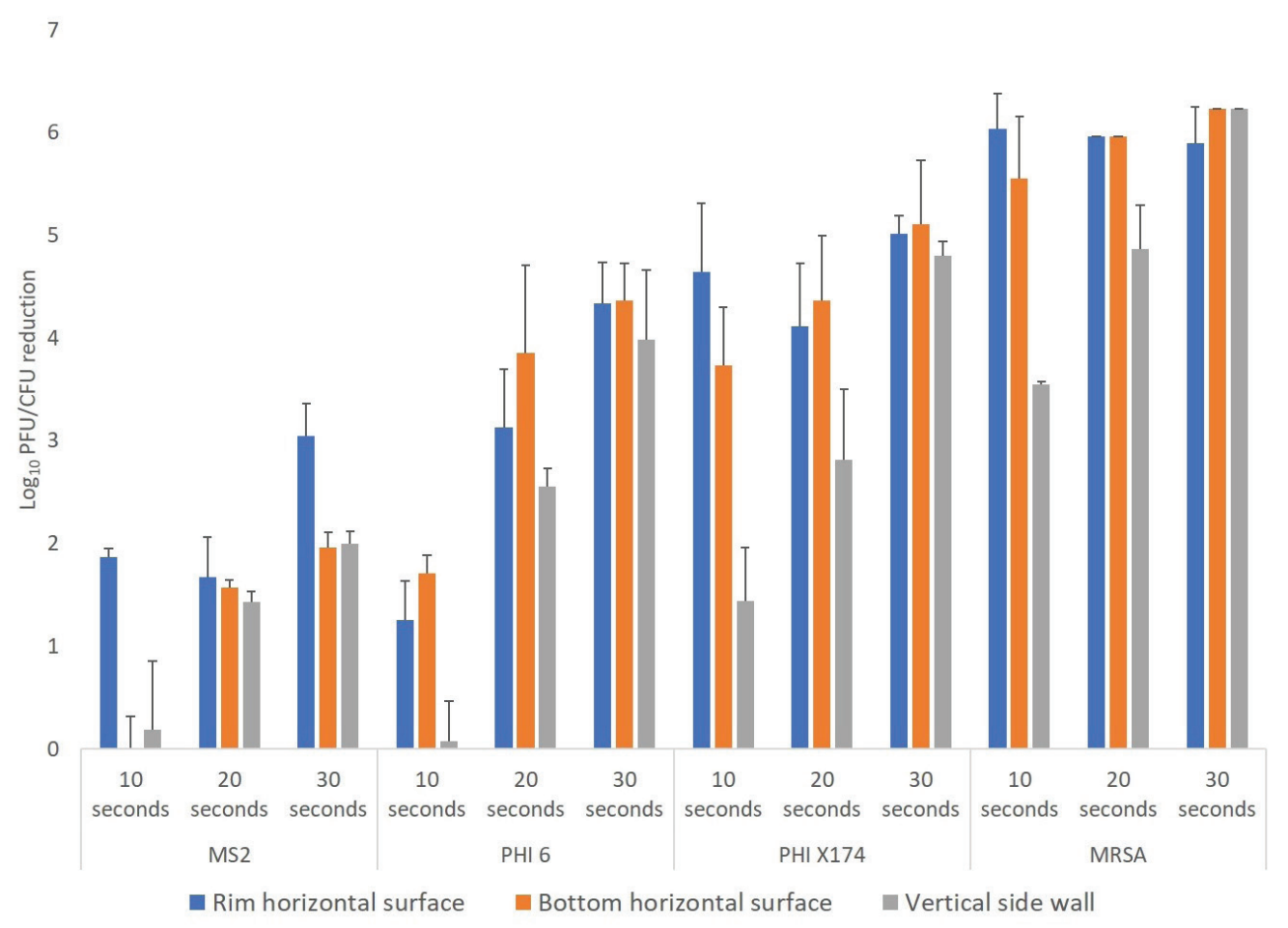

Figure 2. Efficacy of ultraviolet-C (UV-C) light for decontamination of methicillin-resistant Staphylococcus aureus (MRSA), bacteriophage MS2, bacteriophage Phi6, and bacteriophage X174 on plastic bins. Aliquots of $10 \mu \mathrm{L}$ containing $10^{6}$ colony-forming units (CFU) or plaque-forming units (PFU) of the test organisms in $8 \%$ simulated mucus were spread to cover an area of $20 \mathrm{~mm}$ on 3 different areas on the bin 
surface (top rim, horizontal, and vertical) as shown in Figure 1. The bins were exposed to 10-, 20-, or 30 -second cycles of UV-C delivered by 2 UV-C lamps positioned horizontally over the bin. Error bars indicate standard error.

Figure 3 shows changes in the UV-C colorimetric indicators with the 30-second duration UV-C treatment at each inoculum site. The 30-second treatment resulted in a color change from yellow (untreated) to orange indicating delivery of a sufficient dose to reduce MRSA at each test location.
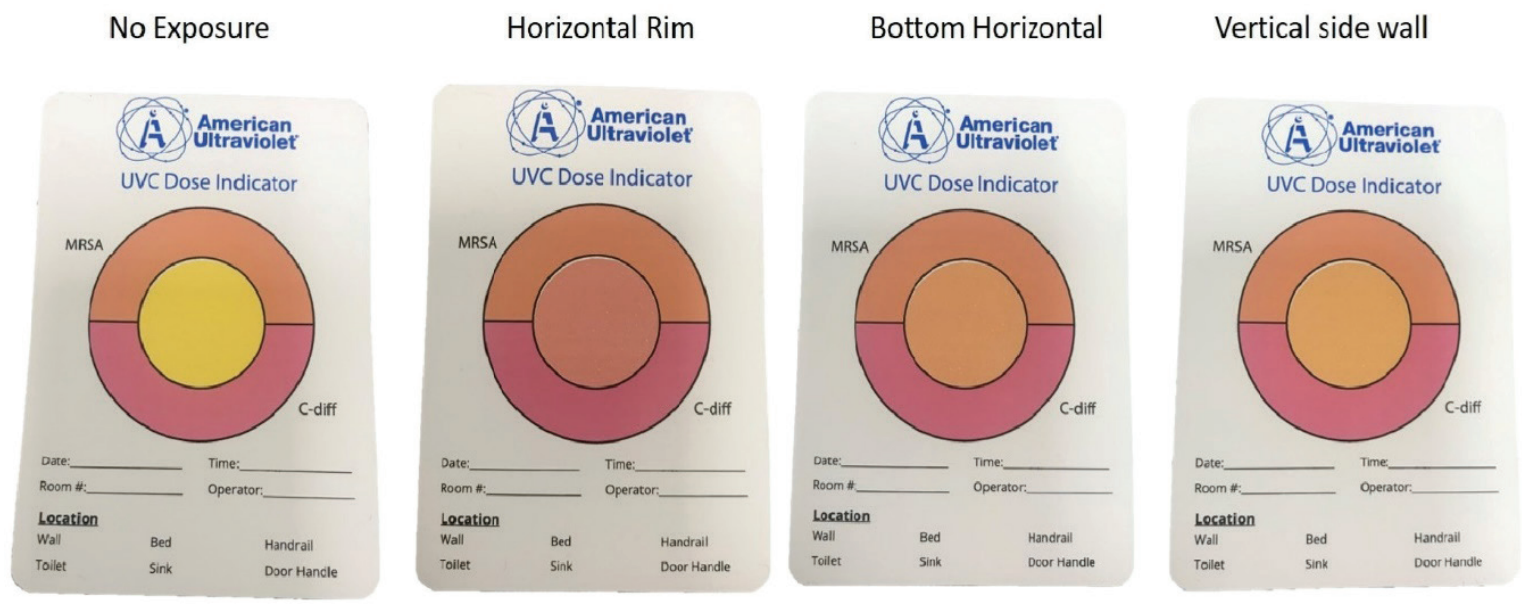

Figure 3. Pictures showing colorimetric indicators (UVC Dose Indicator, American Ultraviolet) placed adjacent to organism inoculation sites shown in Figure 1 during 30-second UV-C cycles. The color of the central circle indicates the level of UV-C exposure: yellow, no exposure; orange, dose sufficient to inactivate methicillin-resistant Staphylococcus aureus (MRSA); pink, dose sufficient to inactivate Clostridioides difficile spores.

\section{DISCUSSION}

Our results demonstrate that short cycles of UV-C could be effective for decontamination of airport security bins. A 30-second UV-C cycle reduced MRSA and the enveloped bacteriophages Phi6 and Phi X174 by greater than $3 \log _{10}$ and reduced the non-enveloped bacteriophage MS2 by greater than $2 \log _{10}$. The greater than $3-\log _{10}$ reduction met our pre-established criteria for decontamination. Our results are consistent with previous studies that demonstrated substantial reductions in pathogens on surfaces with short UV-C cycles delivered in proximity to the treated surface $[\underline{21}-\underline{22}, \underline{24}-\underline{25}]$.

In addition to efficacy, there are several practical issues that make airport security bins an attractive target for application of UV-C technologies. The bins are touched repeatedly by multiple users and by suitcases and personal items in a hurried setting that is not conducive to standard cleaning and disinfection processes. Having passengers use disinfectant wipes before loading bins or spraying bins with liquid disinfectants would not be feasible for repeated applications between each use. In order to apply UV-C to airport security bins, there is a need for a technology that would provide automated movement of bins through a decontamination process with UV-C bulbs positioned on all sides of the bins. One requirement for such a technology would be that the 
UV-C dosing is delivered in an enclosed space that would prevent external or human bystander exposure to UV-C light. Devices that deliver UV-C in an enclosed space have previously been developed for decontamination of touchscreens, keyboards, and small items such as tablets, cell

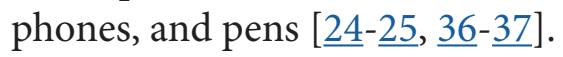

Our study has several limitations. First, we used benign bacteriophages rather than viral pathogens for testing. Further work is needed to evaluate bin decontamination in real-world settings with viral contamination. Second, we only studied one type of bin that was a surrogate for actual security bins. Additional testing with different types of bins is needed. Third, we did not compare the efficacy of UV-C with other technologies or with standard cleaning and disinfection. As noted previously, we anticipate that UV-C is more feasible but not more effective than standard cleaning and disinfection. Finally, we only tested one UV-C cycle. In practice, repeated cycles of UV-C would be delivered after each use of the bins.

In summary, our results suggest that UV-C light could be effective for rapid decontamination of airport security bins. UV-C light is ideally suited for decontamination of hard, smooth surfaces such as security bins that can be positioned close to the light source allowing for short treatment cycles. UV-C light is particularly well-suited for decontamination of items such as security bins that are not readily amenable to standard cleaning and disinfection processes. Thus, UV-C light decontamination merits consideration for security bin decontamination in the setting of concerns regarding transmission of viral respiratory pathogens such as SARS-CoV-2 in airports. Further studies are needed to evaluate the utility of UV-C in real-world settings in airports. There is also a need for development of technologies that would provide automated movement of bins through a UV-C decontamination process. Finally, although the current study focused on security bins, it is acknowledged that similar shared high-touch surfaces such as touchscreens might also be considered for UV-C decontamination.

\section{ACKNOWLEDGMENTS}

\section{Financial support}

This work was supported by a Merit Review grant (1 I01 BX002944-01A1) from the Department of Veterans Affairs to C.J.D.

\section{CONFLICTS OF INTEREST.}

C.J.D has received research grants from Clorox, Pfizer, and PDI. All other authors report no conflicts of interest relevant to this article. J.L.C, D.L., and C.J.D. have submitted a provisional patent for a device to provide automated UV-C decontamination of airport security bins. C.J.D. is also an associate editor for the journal Pathogens and Immunity. 


\section{REFERENCES}

1. Guarner J. Three Emerging Coronaviruses in Two Decades. Am J Clin Pathol 2020;153:420-421. doi: 10.1093/ajcp/aqaa029.

2. Zou L, Ruan F, Huang M, Liang L, Huang H, Hong Z, Yu J, Kang M, Song Y, Xia J, Guo Q, Song T, He J, Yen HL, Peiris M, Wu J. SARS-CoV-2 Viral Load in Upper Respiratory Specimens of Infected Patients. N Engl J Med 2020;doi: 10.1056/NEJMc2001737.

3. Hijano DR, Brazelton de Cardenas J, Maron G, Garner CD, Ferrolino JA, Dallas RH, $\mathrm{Gu}$ Z, Hayden RT. Clinical correlation of influenza and respiratory syncytial virus load measured by digital PCR. PLoS One 2019;14:e0220908.

4. Walsh EE, Peterson DR, Kalkanoglu AE, Lee FE, Falsey AR. Viral shedding and immune responses to respiratory syncytial virus infection in older adults. J Infect Dis 2013;207:1424-32.

5. Otter JA, Donskey C, Yezli S, Douthwaite S, Goldenberg SD, Weber DJ. Transmission of SARS and MERS coronaviruses and influenza virus in healthcare settings: possible role of dry surface contamination. J Hosp Infect 2016;92:235-50.

6. van Doremalen N, Bushmaker T, Morris DH, Holbrook MG, Gamble A, Williamson BN, Tamin A, Harcourt JL, Thornburg NJ, Gerber SI, Lloyd-Smith JO, de Wit E, Munster VJ. Aerosol and surface stability of SARS-CoV-2 as compared with SARS-CoV-1. N Engl J Med 2020. DOI: 10.1056/NEJMc2004973

7. Casanova LM, Jeon S, Rutala WA, Weber DJ, Sobsey MD. Effects of air temperature and relative humidity on coronavirus survival on surfaces. Appl Environ Microbiol 2010;76:2712-7.

8. Boone SA, Gerba CP. Significance of fomites in the spread of respiratory and enteric viral disease. Appl Environ Microbiol 2007;73:1687-96.

9. Phan LT, Sweeney DM, Maita D, Moritz DC, Bleasdale SC, Jones RM; CDC Prevention Epicenters Program. Respiratory viruses in the patient environment. Infect Control Hosp Epidemiol 2020;41:259-266. doi: 10.1017/ice.2019.299.

10. Boone SA, Gerba CP. The occurrence of influenza A virus on household and day care center fomites. J Infect 2005;51:103-9.

11. Fong MW, Leung NHL, Xiao J, Chu DKW, Cheng SMS, So HC, Li Y, Ip DKM, Peiris JSM, Cowling BJ. Presence of influenza virus on touch-surfaces in kindergartens and primary schools. J Infect Dis 2020 Mar 16. pii: jiaa114. doi: 10.1093/infdis/jiaa114.

12. Memish ZA, Almasri M, Assirri A, Al-Shangiti AM, Gray GC, Lednicky JA, Yezli S. Environmental sampling for respiratory pathogens in Jeddah airport during the 2013 Hajj season. Am J Infect Control 2014;42:1266-9.

13. Ikonen N, Savolainen-Kopra C, Enstone JE, Kulmala I, Pasanen P, Salmela A, Salo S, Nguyen-Van-Tam JS, Ruutu P; PANDHUB consortium. Bins Deposition of respiratory virus pathogens on frequently touched surfaces at airports. BMC Infectious Diseases 2018;18:437. doi: 10.1093/jtm/tav002.

14. https://www.cdc.gov/coronavirus/2019-ncov/index.html 
15. Darnell ME, Subbarao K, Feinstone SM, Taylor DR. Inactivation of the coronavirus that induces severe acute respiratory syndrome, SARS-CoV. J Virol Methods 2004;121:85-91.

16. Tseng CC, Li CS. Inactivation of viruses on surfaces by ultraviolet germicidal irradiation. J Occup Environ Hyg 2007;4:400-5.

17. Beck SE, Ryu H, Boczek LA, Cashdollar JL, Jeanis KM, Rosenblum JS, Lawal OR, Linden KG. Evaluating UV-C LED disinfection performance and investigating potential dual-wavelength synergy. Water Res 2017;109:207-216. doi: 10.1016/j. watres.2016.11.024.

18. Lore MB, Heimbuch BK, Brown TL, Wander JD, Hinrichs SH. Effectiveness of Three Decontamination Treatments against Influenza Virus Applied to Filtering Facepiece Respirators. Ann Occupat Hyg 2012;56:92-101. https://doi.org/10.1093/annhyg/ mer054

19. Viscusi DJ, Bergman MS, Eimer BC, Shaffer RS. Evaluation of Five Decontamination Methods for Filtering Facepiece Respirators. Ann Occup Hyg 2009;53:815-827. https://doi.org/10.1093/annhyg/mep070

20. Heimbuch BK, Wallace WH, Kinney K, Lumley AE, Wu C, Woo M, Wander JD. A pandemic influenza preparedness study: use of energetic methods to decontaminate filtering facepiece respirators contaminated with $\mathrm{H} 1 \mathrm{~N} 1$ aerosols and droplets. Am J Infect Control 2011;39:e1-e9.

21. Boyce JM, Donskey CJ. Understanding ultraviolet light surface decontamination in hospital rooms: A primer. Infect Control Hosp Epidemiol. 2019;40(9):1030-1035. doi:10.1017/ice.2019.161

22. Donskey CJ. Decontamination devices in health care facilities: Practical issues and emerging applications. Am J Infect Control 2019;47S:A23-A28. doi: 10.1016/j. ajic.2019.03.005.

23. Smolle C, Huss F, Lindblad M, Reischies F, Tano E. Effectiveness of automated ultraviolet-C light for decontamination of textiles inoculated with Enterococcus faecium. Am J Infect Control 2018;98:102-104.

24. Alhmidi H, Cadnum JL, Piedrahita CT, John AR, Donskey CJ. Evaluation of an automated UV-C device and patient hand hygiene for reduction of transfer from touchscreen computers. Am J Infect Control 2018;46:464-467.

25. Mathew JI, Cadnum JL, Sankar T, Jencson AL, Kundrapu S, Donskey CJ. Evaluation of an enclosed ultraviolet- $C$ radiation device for decontamination of mobile handheld devices. Am J Infect Control 2016;44:724-6.

26. Casanova LM, Weaver SR. Evaluation of eluents for the recovery of an enveloped virus from hands by whole-hand sampling. J Appl Microbiol 2015;118:1210-1216. doi:10.1111/jam.12777.

27. Tomas ME, Kundrapu S, Thota P, Sunkesula VC, Cadnum JL, Mana TS, Jencson A, O'Donnell M, Zabarsky TF, Hecker MT, Ray AJ, Wilson BM, Donskey CJ. Contamination of the skin and clothing of healthcare personnel during removal of personal 
protective equipment. JAMA Intern Med 2015;175:1904-10. doi: 10.1001/jamainternmed.2015.4535

28. ASTM International, Designation E2197: Standard Quantitative Disk Carrier Test Method for Determining Bactericidal, Virucidal, Fungicidal, Mycobactericidal, and Sporicidal Activities of Chemicals, 2011.

29. Masiuk T, Kadakia P, Wang Z. Development of a physiologically relevant dripping analytical method using simulated nasal mucus for nasal spray formulation analysis. J Pharm Anal 2016;6:283-291. doi: 10.1016/j.jpha.2016.05.003.

30. Rutala WA, Kanamori H, Gergen MF, Sickbert-Bennett EE, Weber DJ. Susceptibility of Candida auris and Candida albicans to 21 germicides used in healthcare facilities. Infect Control Hosp Epidemiol 2019;40:380-382. doi: 10.1017/ice.2019.1.

31. Goyal SM, Chander Y, Yezli S, Otter JA. Evaluating the virucidal efficacy of hydrogen peroxide vapour. J Hosp Infect 2014;86:255-9. doi: 10.1016/j.jhin.2014.02.003.

32. Lloyd-Evans N, Springthorpe VS, Sattar SA. Chemical disinfection of human rotavirus-contaminated inanimate surfaces. J Hyg (Lond) 1986;97:163-73.

33. Hulkower RL, Casanova LM, Rutala WA, Weber DJ, Sobsey MD. Inactivation of surrogate coronaviruses on hard surfaces by health care germicides. Am J Infect Control 2011;39:401-407. doi: 10.1016/j.ajic.2010.08.011.

34. Abad FX, Pintó RM, Bosch A. Disinfection of human enteric viruses on fomites. FEMS Microbiol Lett 1997;156:107-11.

35. Lenth R. emmeans: Estimated Marginal Means, aka Least-Squares Means. R package version 1.3.3. 2019. https://CRAN.R-project.org/package=emmeans.

36. Emig E, Alhmidi H, Ng-Wong YK, Mana TSC, Cadnum JL, Donskey CJ. Efficacy of a novel ultraviolet light-emitting diode device for decontamination of shared pens in a health care setting. Am J Infect Control 2020;48:100-102. doi: 10.1016/j. ajic.2019.07.014.

37. Shaikh AA, Ely D, Cadnum JL, Koganti S, Alhmidi H, Sankar C T, Jencson AL, Kundrapu S, Donskey CJ. Evaluation of a low-intensity ultraviolet-C radiation device for decontamination of computer keyboards. Am J Infect Control 2016;44:705-7.

\section{FOOTNOTES}

Submitted April 8, 2020 | Accepted May 15, 2020 | Published May 22, 2020

\section{COPYRIGHT}

Copyright (C) 2020 Pathogens and Immunity.

This is an open-access article distributed under the terms of the Creative Commons Attribution 4.0 International License. 